\title{
The Neglect of Governance in Forest Sector Vulnerability Assessments: Structural-Functionalism and "Black Box" Problems in Climate Change Adaptation Planning
}

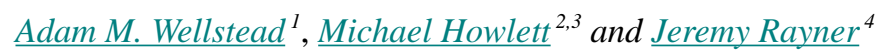

\begin{abstract}
Efforts to develop extensive forest-based climate change vulnerability assessments have informed proposed management and policy options intended to promote improved on-the-ground policy outcomes. These assessments are derived from a rich vulnerability literature and are helpful in modeling complex ecosystem interactions, yet their policy relevance and impact has been limited. We argue this is due to structural-functional logic underpinning these assessments in which governance is treated as a procedural "black box" and policy-making as an undifferentiated and unproblematic output of a political system responding to input changes and/or system prerequisites. Like an earlier generation of systems or cybernetic thinking about political processes, the focus in these assessments on macro system-level variables and relationships fails to account for the multi-level or polycentric nature of governance and the possibility of policy processes resulting in the nonperformance of critical tasks.
\end{abstract}

Key Words: climate change; forestry; governance; structural functionalism

\section{INTRODUCTION: FEASIBILITY IN FOREST} PLANNING FOR CLIMATE CHANGE ADAPTATION

The ability of natural resource sectors to adapt to climate change has become an issue of concern for those charged with forest stewardship and those who derive their livelihoods from forested lands. And, in the wake of failures of multi-lateral and multi-sectoral mitigation efforts like the Kyoto Protocol or the Copenhagen Accord to control greenhouse gases, attention is now focused on national and subnational level sectoral plans for adaptation.

How to develop these plans and what factors or variables to include and account for in order to achieve policy goals are, however, uncertain. In the climate change policy arena, there is a prevalence of "wicked problems" in which the source, framing, and solution to policy problems are all contested (Rittel and Webber 1973). Moreover, many observers argue that successful adaptation will require wholesale behavioral and institutional change at multiple levels, from the individual and the corporation to the state (Gale 2008). Determining both what should be done and what is feasible in present circumstances is thus of great significance to both analysts and practitioners (Gilabert and Lawford-Smith 2012. See also Huitt 1968, Meltsner 1972, Majone 1975), and forest vulnerability assessments and climate change adaptation policies must take both aspects of policy-making into account. However, observing this dual imperative does not always occur.
This is apparent, for example, in the case of many high-profile forest sector adaptation studies. The first steps towards the development of adaptation policies have already taken place in the forest sector, and the contours of the recommendations for government action can now be discerned. These vulnerability assessments and fledgling frameworks have proposed a host of management and policy recommendations but rely upon a form of "structural-functional" reasoning which presents a false sense of what is possible, and proper, in terms of policy processes and outputs. This logic presents management and policy innovations as quasi-automatic responses to climate change-related changes in the forest ecosystems and does not properly account for political and other factors that affect policy-making and policy outcomes.

This problem has been recognized in some of the academic literature on vulnerability, which has drawn attention to the many ways in which structural-functional "input-output" approaches to adaptation overlook the tendency of contemporary forest governance to support the status quo in management options and policy outcomes. While this latter literature remains dominated by empirical case studies, we argue that the time is ripe for a theoretical synthesis of the evidence that it presents. As we argue, governance-related issues will increasingly come to the forefront of adaptation planning exercises but will require significant changes in the logic of assessment frameworks if governance challenges are to be properly accounted for and the outcomes of the frameworks and reports successfully carried through to fruition and implementation. 
The neglect of governance and the persistence of structural functionalism in forest sector vulnerability assessments

Governmental vulnerability assessments are part of a broader trend in natural resource management that attempts to apply vulnerability assessment frameworks to natural resource management issues. A growing number of national and subnational exercises draw heavily upon similar efforts carried out by the larger international epistemic community, notably the Intergovernmental Panel on Climate Change (IPCC) in its Third and Fourth Assessment Reports (Preston et al. 2010). The Third Assessment Report, in turn, draws upon Smit et al. 's (1999) climate change assessment framework, and this general approach has been emulated at the forest sector level. We argue that the current omission of governance considerations in government vulnerability assessment frameworks in these and many other similar reports is founded on an analysis of social and policy processes rooted in highlevel models of ecosystem and community impacts of, and responses to, climate change that were widely discredited in the sociological and political science literature more than 50 years ago. In order to illustrate these problems, we highlight assessments in three major countries: Australia, Canada, and the United States.

In Australia, the National Climate Change Adaptation Research Facility, an initiative of the Australian government, recently released An Assessment of the Vulnerability of Australian Forests to the Impacts of Climate Change. This four-report assessment by leading Australian climate change scholars, based on the IPCC Working Group II's (Smit and Pilifosova 2001) pioneering framework, was initiated in order to "provide information to assist governments, natural resource management managers and the business sector to adapt to the changing climatic environment in a manner consistent with principles of sustainable forest management" (Wilson and Turton 2010). In their report, Climate Change Adaptation Options, Tools and Vulnerability, Wilson and Turton (2010) acknowledge that very little is understood about governance mechanisms, and the subject is sparingly discussed. However, when it is mentioned, governance is treated simply as a variable that constrains adaptive capacity. Cockfield et al.'s (2011) report, The Socio-economic Implications of Climate Change, for example, states that "with regard to forests and forest management accelerating impacts may lead to classic paradigmatic change but the need for the adaptive governance of social-ecological systems" (p. 57). This trend of conceptualizing governance as an input variable in a social-ecological system is also prevalent in North American assessments.

In the Canadian forest sector, for example, the intergovernmental Canadian Council of Forest Ministers (CCFM) commissioned a Task Force with the primary goal of providing "the forest sector with state-of-the-art tools and new knowledge that will allow them to assess the vulnerabilities, risks, and opportunities associated with climate change" (Canadian Council of Forest Ministers 2012). One of these tools, very similar to the Australian effort, is Adapting Sustainable Forest Management to Climate Change: A Framework for Assessing Vulnerability and Mainstreaming Adaptation into Decision Making (Williamson et al. 2012). One of the key components of the CCFM framework is adaptive capacity, which is defined as "the ability of a system to adjust to changing internal demands and external circumstances" (Carpenter and Brock 2008). Moreover, adaptive capacity in the CCFM framework is "represented as a function of specific determinants such as the effectiveness of institutions, the availability of technological options, the availability of human and social capital (e.g., skills, education, experience, and networks), information and information management, financial resources and natural capital, and the capacity for risk management" (p. 11). Williamson et al. (2012) also highlight adaptive capacity deficits that are the "results of factors causing under- or overinvestment in adaptive capacity 'assets' that may arise due to market, governance, institutional, and social system failures." As a result, governance is again treated not as a major independent determinant of policy content but simply as another input variable that needs to be calibrated in order to positively affect adaptive capacity.

Provincial governments in Canada, which have primary jurisdiction in the forest sector, have also undertaken similar vulnerability assessments and developed their own adaptation frameworks. For example, the 2009 Expert Panel on Climate Change Adaptation in Ontario led to the development of the Ontario Climate Change Action Framework, which was to be a blueprint for all sectors. It argued that the establishment of "good governance" was an important component of its adaptive decision framework, which was seen as the beginning of a planning cycle leading to a vulnerability assessment, then a risk assessment, and then finally the development of adaptation options (Government of Ontario 2011). This assessment, too, treats government and governance as easily manipulated reactive or automatic system variables. The department responsible for forest management, the Ontario Ministry of Natural Resources, has been tasked with developing a Forest Adaptation Assessment (Government of Ontario 2011).

In the United States, the USDA Forest Service has also followed the "vulnerability assessment framework" path by developing a "Strategic Framework for Responding to Climate Change" and a "National Roadmap for Responding to Climate Change." These strategies were also the result of comprehensive vulnerability assessments (USDA Forest Service 2010). However, unlike the Australian and Canadian 
cases, the U.S. Forest Service also implemented a "Climate Change Performance Scorecard." The scorecard was to be implemented in all National Forests and Grasslands and would report on-the-ground accomplishments and plans for improvement in four dimensions-organizational capacity, engagement, adaptation, and mitigation (USDA Forest Service 2011). Within the adaptation dimension, vulnerability assessments would "assess the vulnerability of key resources to the impacts of climate change and the interaction with other stressors and human communities" (USDA Forest Service 2011). However, despite its pivotal role in subsequent policy specification and adoption, the role of government and governance is notably absent from this document.

Thus, despite the efforts and resources dedicated to developing the above three frameworks, they all fail to seriously incorporate a substantive and coherent governance analysis but rather treat government as just another system variable. Ironically, this limited view of governance may inhibit the formulation of meaningful adaptation policy-making that is sought out by the government agencies that fund these assessments. While these assessments are heuristically valuable tools, further development of key concepts, such as governance, is required in order for government policy-makers and analysts to have a critical and meaningful dialogue about the steps required to address and implement climate adaptation in the forest sector.

In contrast to the forestry vulnerability assessment frameworks, a new generation of adaptation case studies, motivated in part by the apparent failure of real communities to respond as the vulnerability models predicted, does raise concerns about the need to properly understand and incorporate governance-related challenges into proposals for policy change (Preston et al. 2010). Keskitalo's (2009) investigation of adaptation in reindeer herding, forestry, and fishing communities in northern Norway, Sweden, and Finland, for example, "highlights the political and interestbased character of governance, where distribution of power rather than physical risk may be determining institutional interactions" (p. 201). Raitio's (2012) case study of collaborative planning "as a multilevel practice embedded in institutions" (p. 315) demonstrates the difficulty of translating collaborative approaches (often a key recommendation in adaptation frameworks) from one regulatory context to another. Wall and Marzall's (2006) attempt to make the theory-empirical link in their development of a Canadian rural community-level framework for adaptive capacity is another example that recognizes the need to treat government as more than just another system variable (see also Brooks et al. 2005, Lebel et al. 2006, Norris et al. 2008, Brown 2009, Davidson 2010, Gupta et al. 2010, Termeer et al. 2010, Keskitalo et al. 2011).
However, not all adaptation studies take this approach and many retain the same faults as those of the vulnerability studies cited. For example, Engle and Lemos (2010) note the importance of "governance and institutional mechanisms" as determinants in characterizing adaptive capacity, and rank a suite of governance and institutional indicators for communities in Brazil's river basins. Nonetheless, the key political and governance considerations that would explain how the indicators will be used to coordinate activities aimed toward adaptation goals in the absence of political commitment from government and how that commitment emerges from political conflict are missing. In such cases, the analysis jumps quickly and uneasily between high-level abstraction and microlevel policy recommendations, and skips over the "missing middle" of governance variables, which are critical to joining the two levels together in practice (Nilsson et al. 2011, Voß and Borneman 2011).

\section{THE CURRENT STATE OF VULNERABILITY ASSESSMENT FRAMEWORKS ON GOVERNANCE AND CLIMATE CHANGE ADAPTATION IN NATURAL RESOURCE SECTORS}

The absence of considerations of meso-level governance or societal steering activities and capacities in the framework literature means the lack of impact on the ground among policy-makers from the new generation of case studies is hardly surprising. The models upon which they draw were developed for other reasons, such as ecosystem impact modeling and studies of community resilience (Walker and Cooper 2011), and they are not suited to policy analysis without significant modification, which as we have seen, is rarely done. Although currently in vogue in many geography and natural resource management programs, these models are not well suited to the development of feasible policy prescriptions or to the actual practices of policy-making, where the issues of political power, unequal resource distribution, and institutional legacies noted in the case studies are very central concerns which cannot simply be ignored or glossed over (D’Alessandro et al. 2010, Skodvin et al. 2010).

We argue that, ultimately, the difficulties encountered in moving from the macro or system level to the policy (meso) level in forest sector climate change adaptation frameworks result from a failure of existing models and analyses to include or properly conceptualize and weight the role played by mesolevel institutional and political variables in mediating between macrolevel ecosystem and social system parameters and microlevel actor behavior and outputs. This omission, we argue, is in turn attributable to the structural-functional logic that imbues the many models and frameworks used in vulnerability and climate change assessments (Hempel 1959, Greenstein 1973, Parsons 1975). This logic is one that simply assumes that governance activities will be performed in 
Fig. 1.Modification of Fussel and Klein's (2006) Adaptation Policy Processes Model.

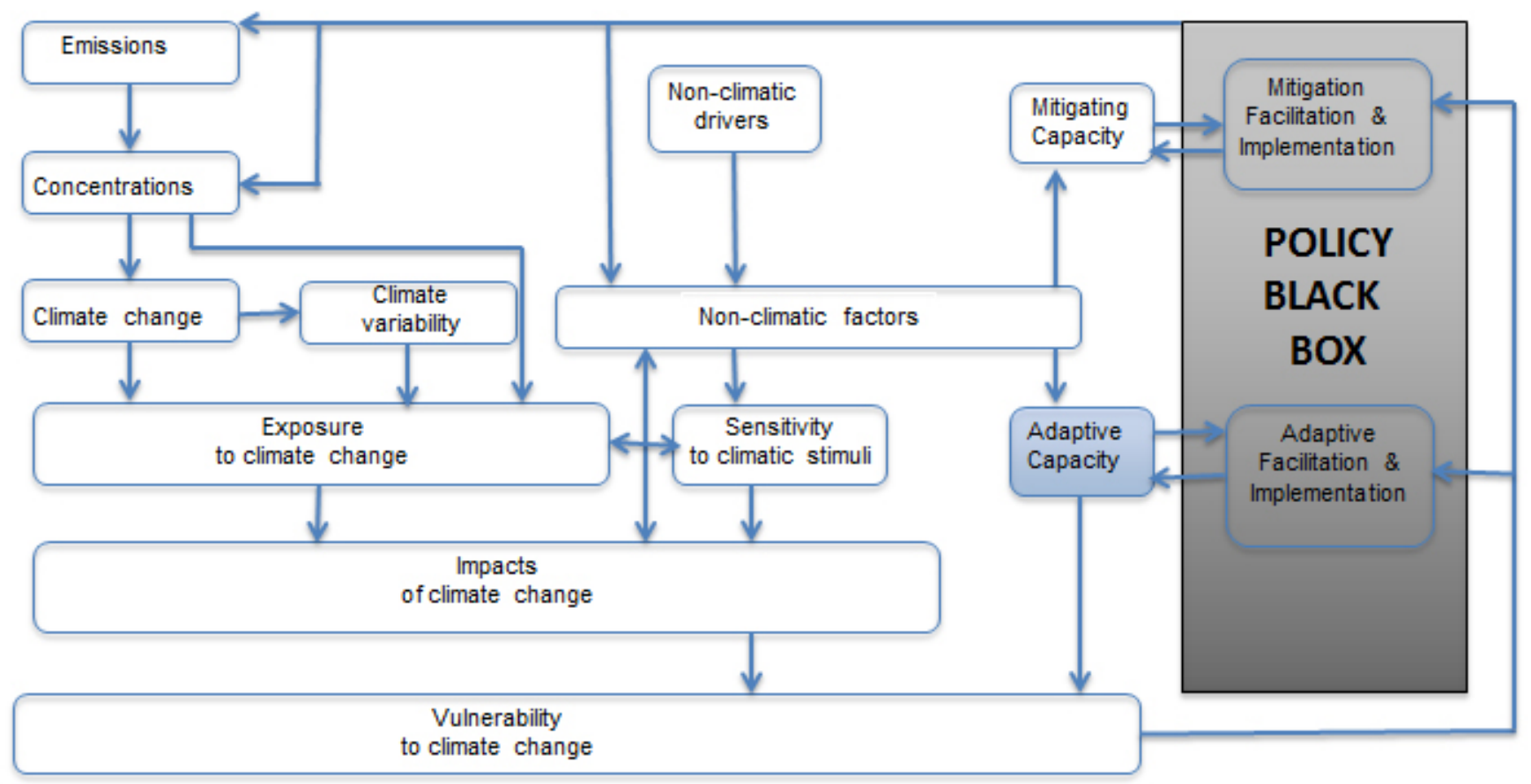

specific ways due to system-level prerequisites (Cummins 1975), and ignores the complexity of the policy process itself and the possible nonperformance of mission critical tasks (Howlett, Ramesh, and Perl 2009, Wu et al. 2010, Weible et al. 2012). Like an earlier generation of systems or cybernetic thinking about political processes and outcomes, many vulnerability assessment frameworks treat government as a procedural "black box" in which policy-making is an undifferentiated and unproblematic activity of a political system which takes place in the context of system needs and inputs (Easton 1965). As was pointed out more than half a century ago in the context of criticisms of the then prevalent structural-functional sociological theory, this exclusive focus on macro systems-level variables and relationships fails to account for many key political variables that affect policymaking, and therefore serves as a very poor predictor of actual activity on the ground (Barber 1956).

\section{The resurgence of structural functionalism in vulnerability assessment frameworks}

The first problem in nearly all vulnerability assessment frameworks is the wholesale neglect or severe underspecification of political variables, in particular those dealing with policy-making, a neglect that is the direct result of the functional logic underlying them (Cummins 1975).

Fig. 1 from Füssel and Klein's (2006) well-known and oftcited $^{[1]}$ assessment of climate change adaptation policy processes typifies the main components of these functional approaches to adaptation (Fig. 1). The authors draw their analysis from earlier contributions, namely Smit and Wandel (2006), as well as resilience studies such as Adgar (2006), Folke (2006), Gallopin (2006), and Nelson et al. (2007). ${ }^{[2]}$

As Fig. 1 shows, the structural framework is pitched at a very high level of generality and attempts to model relationships existing among various ecosystem elements related to measures such as exposure, sensitivity, impacts, adaptive capacity, vulnerability, and adaptation at the macro or systems level. The level of generality is clear even in the definition of "adaptation" in these models, which refers to "the adjustment in natural or human systems in response to actual or expected climatic stimuli or their effects, which moderates harm or exploits beneficial opportunities." Similarly, adaptive capacity is concerned with "the ability of a system to adjust to climate change (including climate variability and extremes) to moderate potential damages, to take advantage of opportunities, or to cope with the consequences" (Füssel and Klein 2006, p. 18).

It is important to note that politics, governance, and policymaking are not defined or further analyzed in this assessment model, and, in general, political relationships are understood as a kind of input variable promoting adaptation "functions" (Holling 1973, 2001, Folke et al. 2002). Füssel and Klein (2006), for example, state that there are two important 
Table 1.Treatment of governance in the vulnerability assessment literature.

\begin{tabular}{|c|c|}
\hline Author & Discussion of governance \\
\hline Adger (2006) & $\begin{array}{l}\text { "The remaining challenge is in combining measurement of aspects of vulnerability and thresholds } \\
\text { within systems with explanations of whole-system vulnerability and the role of institutions and } \\
\text { governance processes." (p. 275) }\end{array}$ \\
\hline Brooks et al. (2005) & $\begin{array}{l}\text { "The results from the focus group exercise emphasizes the importance of governance indicators." (p. } \\
\text { 161) }\end{array}$ \\
\hline Engle and Lemos (2010) & $\begin{array}{l}\text { "Among those, governance and institutional mechanisms represent one set of system attributes that } \\
\text { scholars believe is particularly important." (p. 5) }\end{array}$ \\
\hline Lebel et al. (2006) & $\begin{array}{l}\text { "The kinds of attributes we are initially interested in are those frequently considered to be part of } \\
\text { 'good' governance, e.g., participation, representation, deliberation, accountability, empowerment, } \\
\text { social justice, and organizational features such as being multilayered and polycentric." }\end{array}$ \\
\hline & $\begin{array}{l}\text { "A capacity for self-organization means that a system has ways to maintain and re-create its identity. } \\
\text { Although most systems are linked to, and impacted by, other systems, self-organizing systems are } \\
\text { able to buffer the impacts of other systems and do not need to be continually invested in, subsidized, } \\
\text { or replenished from outside to persist." }\end{array}$ \\
\hline
\end{tabular}

adaptation-related functions that governments perform: facilitation and implementation. Facilitation refers to activities that enhance adaptive capacity, such as scientific research data collection, awareness raising, and capacity building, and the establishment of institutions, information networks, and legal frameworks for action. Implementation refers to activities that actually avoid adverse climate impacts on a system by reducing its exposure or sensitivity to climatic hazards or by moderating relevant nonclimatic factors. This literature thus typically notes the importance of political institutions in addressing adaptation and adaptive capacity but models these variable only in very general terms, with a lack of specifics with regard to the mechanisms and relationships involved in deriving policy recommendations and instrument choices (Daedlow et al. 2011).

Adger et al. (2007), for example, state only that adaptive capacity is influenced by "the nature of governance structures," while Adger (2006) notes only that the role of institutions and governance processes "needs to be considered" along with the physical production and social variables that compose the system in applying this model to policy-making and outcomes. Brooks et al. (2005) similarly develop a suite of governance proxies for national-level vulnerability to climate change (e.g., political stability and rule of law), but the specification of exactly how these variables affect policy dynamics "on the ground" is missing. Plummer and Armitage (2007) also identify capacity and capacity building, institutions, social capital and networks, learning, and vulnerability and livelihoods as critical in their assessment framework, which in turn are argued to influence environmental governance, but without any details on how such processes actually work in either theory or practice. And Smit and Wandel (2006) state only that "improvements in institutions" may lead to increased adaptive capacity, without clarifying the conditions under which this is likely (or not) to occur.

A review of leading contributions in the climate change vulnerability assessment field reveals a similar emphasis on a macrolevel function treatment of governance in many studies. ${ }^{[3]}$ Quotes from a sample of such articles are highlighted Table 1. The functional logic of these analyses, which ignores meso-level governance institutions and processes, is set out in Fig. 2.

Fig. 2. Structural functional logic of vulnerability assessment frameworks.

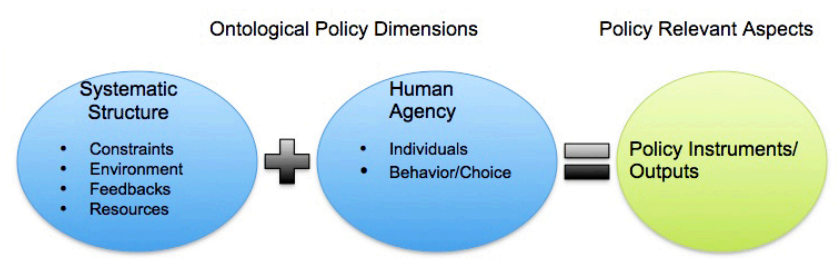

While even these vulnerability assessment frameworks can provide a useful heuristic, the functionalist assumptions inherent in these approaches leave much to be desired in terms 
of understanding or accurately characterizing political phenomena, including activities like public policy-making, law-making, and legislative and administrative behavior, and are of little use to actual policy-makers. For example, as the renowned Norwegian social and political theorist Jon Elster (1986) noted, functionalism is a "puzzling and controversial" mode of explanation in general because, unlike other scientific modes such as causal or intentional explanations (where the intended consequences occur earlier in time), early events are explained by another event later in time (p. 31). Thus, in a functional explanation, "we cite the actual consequences of the phenomenon in order to account for it" (p. 31). Feedback loops are the essential mechanism in functional reasoning because they provide "a causal connection from the consequences of one event of the kind we are trying to explain to another, later event of the same kind" (p. 32). However, in social and political situations, as Elster further argued, such explanations are "only applicable when a pattern of behavior maintains itself through the consequences that benefit some group, which may or may not be the same group of people displaying the behaviour" (p. 32). That is, an institution or a behavioral pattern $\mathrm{X}$ is explained by its function $\mathrm{Y}$ for group $\mathrm{Z}$ if and only if (1) $\mathrm{Y}$ is an effect of $\mathrm{X}$, (2) $\mathrm{Y}$ is beneficial for $\mathrm{Z}$, (3) $\mathrm{Y}$ is unintended by the actors producing $\mathrm{X}$, (4) $\mathrm{Y}$ (or at least the causal relationship between $X$ and $Y$ ) is unrecognized by the actors in $\mathrm{Z}$, and (5) Y maintains $\mathrm{X}$ by a causal feedback loop passing through $\mathrm{Z}$ (p. 28).

Most attempts to use functionalism in social and political explanations fail because they are missing one or more of these five features (Elster 1985). And, as Elster further noted, in political life there are many examples of singular, nonrecurring events that produce unintended policy consequences (such as wars, riots, and rebellions), while feedback loops are often postulated or tacitly assumed when they do not in fact exist (Elster 1986). This is just as true of current forest sector vulnerability assessments as it was of many social theories and frameworks developed in the midtwentieth century which Elster criticized.

\section{The "black box" problem: incorporating policy-making into climate change adaptation models}

Even when some political and other similar variables are incorporated into a vulnerability assessment framework, a second problem arises due to the lack of specificity about the mechanisms and internal workings of institutional and other components of political systems and policy subsystems: the so-called black box problem of unspecified processual variables and mechanisms.

Such concerns about the limitations of high-level systemstheoretic models when applied to policy-making also surfaced more than 40 years ago when these models first emerged in the social sciences. And many of these same concerns resurface in forestry climate change vulnerability assessments today (Black 1961, Gregor 1968, Landau 1968, Stephens 1969). Like their contemporary climate change counterparts, 1960s-era political scientists such as Gabriel Almond (1965) and David Easton (1965) and many others suggested that a high-level cybernetic view could explain much political behavior and outcomes. Following general systems theory scholars such as von Bertalanffy (1969), they argued that the political system existed within an environment that inputs resources and demands into the system and produces outputs (decisions and supports) that operate with feedback loops back to the environment and system inputs. ${ }^{[4]}$ As Fig. 3 shows, this model described government or a political system as a simple feedback system in which a black box converted inputs into outputs, which in turn, fed back into the environment to generate new inputs.

Fig. 3. The "black box" model of political system. Source: adapted from Easton 1965

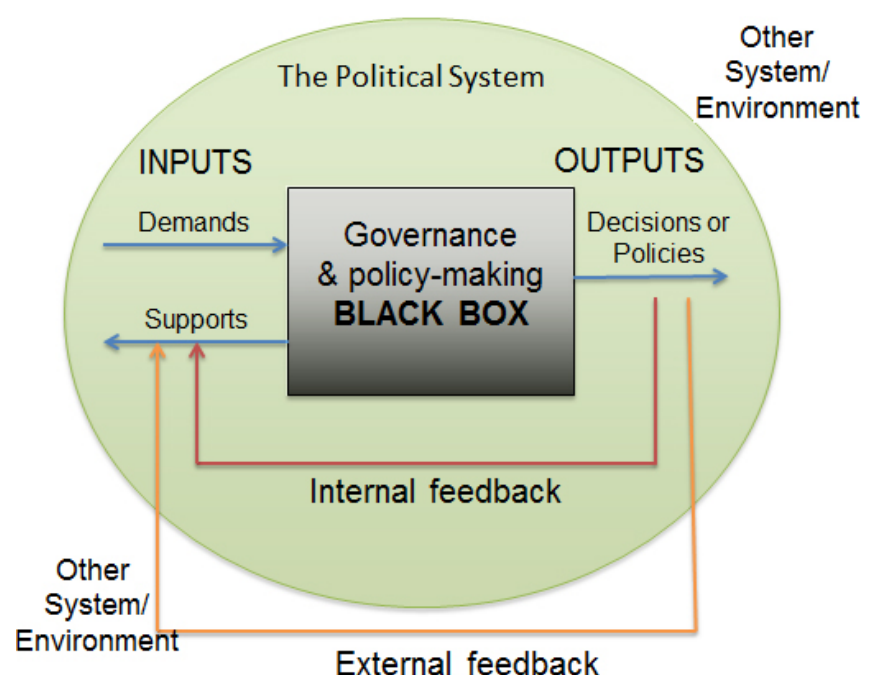

As early as the 1970s, however, this overly abstract and general conception of a political system as a resource conversion mechanism had already been largely discredited. For example, Lilienfeld (1978) labeled systems theory an "ideological movement" because of its tendency to assume that systems maintain themselves in a state of equilibrium, and concluded that it contained little relevance to the real world where actors actively sought and produced change, and had even less practical application. Similarly, Chilcote (1994) found black box systems-level frameworks did little to explain political or policy change, yielded few testable hypotheses, and presented a strong ideological underpinning that sought to downplay political conflict and promote a technocratic understanding and approach to political life. Thorson (1970) found the whole 
enterprise futile so long as the black box of real political processes remained unopened and unexamined. Groth (1970) found that "structural-functionalism has run aground trying to specify its model of the social system untangled by monumental ambiguities and values in the guise of survival considerations" (p. 499). Such an approach has also failed convincingly to establish at least some underlying social and political relationships as "behavioural universals for these allegedly goals of survival and adaptation" (Groth 1970, p. 499).

In response to these kinds of concerns with high-level systems theory, social scientists developed a range of micro- and middle-range theories that permitted theoretical development while allowing for empirical investigation of political and policy processes, hypothesis testing, and careful model building based on empirical results (Merton 1968, Weick 1974). These approaches, now taken for granted in political science, examine specific processes in systems models by focusing on institutions that serve as intermediate variables at the micro and meso levels affecting policy-making within a macro systemic context. Taken together, these studies opened up the highly abstract black box of government processes found in systems thinking, and promoted a more rigorous, empirically based understanding of political life and policy processes and outcomes (Howlett, Ramesh, and Perl 2009).

Climate change adaptation vulnerability assessments, including in the forest sector, still await this institutional "revolution" (Hall and Taylor 1996, Peters 1999). While such an orientation has begun to appear in some of the case study literature cited, like earlier generations of social cybernetic or system theories, much systems-inspired modeling in the climate change adaptation area continues to rely upon structural-functionalist tautologies. That is, what are in fact some of the most determinate actors and variables in any policy-making process-politics and government-are simply assumed away in the belief that policy goals will just be set, and met, since they are "necessary" for the system to "function."

For example, according to Brown (2009), the vulnerability of Ontario's forest sector “is reflective of (or a function of) the exposure and sensitivity of that system to hazardous conditions and the ability or capacity or resilience of the system to cope, adapt or recover from the effect of those conditions" (p. 517) . This analysis provides absolutely no systematic examination of how political and policy institutions actually operate in practice nor any determination of whether or not, or under what circumstances, they might be capable of "delivering the goods" with respect to climate change adaptation outcomes. This institutional logic is set out in Fig. 4 and can be compared with the structural-functional logic of Fig. 2.

\section{MOVING BEYOND STRUCTURAL- FUNCTIONALISM: IMPROVING CLIMATE CHANGE VULNERABILITY ASSESSMENTS BY INCORPORATING THE GOVERNANCE DIMENSION}

The ultimate purpose of climate change vulnerability assessments, of course, is to accurately inform policy-makers of the necessary directions and procedures through which climate change adaptation can be accomplished. And it is here that paying more attention to governance arrangements and institutions is most crucial (Koliba et al. 2011). The meso dimensions that are most often missing from complex adaptive systems theorizing are precisely the most critical in affecting on-the-ground policy change and implementation.

Fig. 4. Policy logic with institutional factors included.

\begin{tabular}{|l|l|l|l|}
\hline System Level & Political Actors & $\begin{array}{l}\text { Policy-Relevant } \\
\text { Aspects }\end{array}$ & $\begin{array}{l}\text { Analytical/Modeling } \\
\text { Assumptions }\end{array}$ \\
\hline $\begin{array}{l}\text { Micro: Human } \\
\text { Agency/ } \\
\text { Behavioral }\end{array}$ & Individuals & Behavior/Choice & $\begin{array}{l}\text { Assumed to be } \\
\text { "rational"vis a vis } \\
\text { system requirements } \\
\text { ("functions") }\end{array}$ \\
\hline $\begin{array}{l}\text { Meso: } \\
\text { Organizational } \\
\text { Structural } \\
\text { Considerations }\end{array}$ & Government & $\begin{array}{l}\text { Governance: State- } \\
\text { Societal Relations }\end{array}$ & BLACK BOX \\
\hline $\begin{array}{l}\text { Macro: } \\
\text { Systemic }\end{array}$ & Environment & $\begin{array}{l}\text { Resources/Constraints/ } \\
\text { Feedback }\end{array}$ & $\begin{array}{l}\text { Assumed to impact } \\
\text { governmental and } \\
\text { individual behavior }\end{array}$ \\
\hline
\end{tabular}

Without taking meso-level variables more seriously in their analyses, as Ascher (2001) argued, the outcomes from employing vulnerability assessments are likely to lead, at best, to a range of poor results due to unintended consequences, the promotion of perverse incentives, and other kinds of policy failures linked to the adoption of infeasible policy alternatives (Marsh and McConnell 2010, McConnell 2010). Such analyses, for example, fail to adequately address governancerelated impacts of even such basic policy-making structures as federalism or the territorial division of powers between governments, the so-called basic multilevel or polycentric nature of contemporary governance (Ostrom 2008, 2009, McGinnis 2000, Aligica and Tarko 2011, Enderlein et al. 2011). ${ }^{[5]}$

In order to enter the realm of feasibility and to achieve practical relevance, adding meso-level of institutional variables to climate change vulnerability and subsequent adaptation is a prerequisite. This involves moving beyond structural functionalism and in direct contrast to the high level of abstraction and tendencies of such logics, governance research focuses upon and seeks to incorporate the details of formulation and implementation efforts involving multiple actors in complex models of patterns of political and policy interaction (Treib et al. 2007). 
In its broadest sense, governance is a term used to describe the different possible modes of government coordination of nongovernmental actors (Rosenau 1992, Kooiman 1993, 2000, de Bruijn and ten Heuvelhof 1995, Rhodes 1996, Klijn and Koppenjan 2000). Governments control the allocation of resources between social actors by providing a set of rules and operating a set of institutions that set out "who gets what, where, when, and how" in society and managing the symbolic resources of state legitimacy. This is the basis of governing, and involves the establishment of relationships between governments and nongovernmental actors that can vary from highly structured and controlled to arrangements that are monitored only loosely and informally, if at all. Governance is about establishing, promoting, and supporting specific types of relationships between governmental and nongovernmental actors, and governance considerations have an important impact on policy processes and decision-making, largely absent in vulnerability assessments.

In large part because of the complexities, uncertainties, and ambiguities of resource and environmental issues noted, environmental policy has been a key venue for governance studies, and forest assessments could benefit from this work. Lacking the knowledge or the mandate to govern alone, governments in this area have increasingly chosen to try to construct policy consensus through more engaged and interactive forms of policy-making and to allow nonstate actors to implement those policies within a broad framework of incentives, benchmarking, and private governance (Sprinz and Vaahtoranta 1994, Zito 2007). This is true in many areas where efforts have been made to develop integrated strategies such as forestry and coastal marine ecosystem management (Howlett and Rayner 2006a, 2006b), and similar efforts are typical in both climate change mitigation and adaptation efforts (Voss et al. 2006). In these new governance modes, the lines between public and private have become blurred (Gatto 2006). From a mode of coordination based on hierarchical topdown, command and control by government actors or their agents, governments have increasingly experimented with new modes of governance that rely on the incentives provided by markets and by the sharing of information in governance networks. Recent advances in the natural resource governance literature have sought to capture these governance dynamics and their effects on policy-making (Tollefson et al. 2008, Howlett, Rayner, and Tollefson 2009). Without incorporating such logics, recommendations stemming from well-meaning vulnerability assessment may not only be misleading, but incorrect, out of date, and moving against the current of contemporary governance and policy instrument choices.

\section{OPENING UP THE BLACK BOX: REVISUALIZING THE POLICY PROCESS IN CLIMATE CHANGE ADAPTATION MODELING}

The neglect of institutional variables in climate change studies is not unique. As Nilsson et al. (2011) have argued, this neglect has also occurred in high-level energy systems studies, which share many similar characteristics in vulnerability assessment frameworks. As they put it:

\section{The hitherto superficial treatment of institutions and politics in energy future studies is somewhat surprising. Many literatures concerned with systems-technical change recognize the importance of institutions in shaping (and interacting with) technological systems. These insights have emerged not only in economic history, sociology and political science, but also prominently in innovation systems studies, evolutionary and institutional economics, socio-technical systems, and even more recently in transitions management and elsewhere. These perspectives share several insights about institutions, what they are, why they are relatively stable and how they change. (p. 1117-1118)}

Understanding the role that meso-level variables play in climate change adaptation begins by incorporating governance logics into vulnerability assessment frameworks. Three specific aspects of policy-making that affect instrument choices within specific governance contexts need to be explicitly modeled in these frameworks. The first dimension is linked to the structure and pervasiveness of policy networks, which address the balance of power between state actors and the societal actors and networks, which in turn, are linked to the kinds of policy instruments that are chosen to give effect to new governance arrangements (Howlett 2002, 2011). In this network dimension, the number and diversity of actors (state and nonstate) that exert some degree of power or influence over the outputs of the governance arrangements is a key facet of policy-making (Knoke and Kuklinski 1982, Knoke 1987). In this respect, the concern of the analyst is to identify where political power lies in relation to society and the state (Lukes 1974, Lindblom 1977, Katzenstein 1978, Offe 1984). The challenge is to determine whether, and to what extent, in specific sectors and issue areas the state or its agents are directly dictating the outcomes that emerge from the governance arrangement, more loosely "steering" the arrangement, or alternatively whether ultimate power to determine outcomes rests with nonstate actors (e.g., corporations, unions, environmental civil society organizations) (McCool 1998).

The second dimension has to do with the rigidity of institutional policy-related arrangements-namely their formal or informal nature. The institutional aspects of governance arrangement can be assessed in terms of factors such as precision (how closely it constrains private action), obligation (the "bindingness" of its commands), and delegation (the extent to which the power to adjudicate and enforce these obligations is retained by a regulator or delegated to an independent third party) (Tollefson et al. 2012). Recently, Doelle et al. (2012) explored these two dimensions in a study 
of climate change-based forest governance arrangements in Canada, New Zealand, and the U.S.

Finally, the third dimension, the policy process, illustrates the dynamic features of governance arrangements by focusing on policy-making and policy change. The policy cycle (Hill 2007, Howlett, Ramesh, and Perl 2009, Pal 2010, Wu et al. 2010) and policy change frameworks (e.g., advocacy coalition framework, institutional rational choice, and structural choice) (Moe 1984, Ostrom 1991, Schlager and Bloomquist 1996, Sabatier and Jenkins-Smith 1999) are familiar approaches that draw upon the network and institutional dimensions and provide an even finer, more empirical lens on understanding the complexity and challenges of governance. Stedman et al. (2004), Wellstead and Stedman (2007, 2011), and Rayner et al. (2013) utilized these approaches in their examination of climate change adaptation policy formulation in the Canadian agriculture, forestry, and water sectors.

As Fréchette and Lewis (2011) argue:

In order to develop a comprehensive understanding of the dynamics of change, analysts require a metatheoretical approach that not only provides complementary insights into how rules change over time, but also pushes the boundaries of conventional analysis to consider the constitutional arrangements that structure collective action and the subsequent performance of forest governance structures. (p. 582)

The use of this kind of framework allows us to open the black box of governance and assess the feasibility of particular policy prescriptions, which is, after all, the intent of forest managers who have invested time and resources into vulnerability assessments. This analysis also overcomes the unrealistic assumption that governance will simply "get done" as a kind of system maintenance activity.

\section{CONCLUSION AND IMPLICATIONS}

Many existing climate change adaptation frameworks and vulnerability assessments suffer from conceptual weaknesses which limit their accuracy and policy relevance. These weaknesses can be summarized under three headings. First, they follow an implicit structural-functionalist logic which treats governments as a black box and policy-making as undifferentiated and unproblematic. This results in the second problem: a failure to take into account the complex multilevel or polycentric nature of contemporary policy-making and governance. These two problems, in turn, lead to a third: the tendency to make recommendations for policy action which are infeasible or difficult if not impossible to implement in current circumstances.

Fortunately, the new generation of adaptation case studies now appearing is much more aware than past ones of the importance of incorporating and analyzing meso-level factors such as institutions and policy instruments for the success of adaptation strategies. Klenk et al. (2011), for example, use the framework of reflexive modernization to highlight governance obstacles to achieving sustainable forest management goals. While some studies have explicitly recognized the need for a theoretical synthesis that addresses governance variables in natural resource and environmental studies without appealing to functionalist explanations of how these variables affect other system components, these remain few and far between.

This development in resource management studies echoes that in other sectors that have also pointed out the advantages to practitioners of incorporating governance into macrolevel systems thinking. For health care, for example, Gómez (2011) has argued that:

The practitioner community stands to gain from applying these theoretical approaches to their analysis of the institutional aspects of health governance and health system governance. Instead of merely measuring the presence of elite stewardship, strategic vision, responsiveness, and the like, this alternative approach suggests that practitioners begin their analysis by specifying the following issues: political and bureaucratic elite beliefs, interests, and the supportive coalitions that motivate elites to become stewards, visionaries, and to pursue institutional change. In contrast to the existing literature, this approach therefore sees elite interests and coalitions as key independent variables while the aforementioned health governance and health system governance indicators are treated as outcomes to be explained. (p. 210)

Our necessarily brief discussion of the theoretical foundations of vulnerability assessments for climate change adaptation is intended to further such efforts by highlighting the complexity of governance arrangements and the need to adequately model and account for them in adaptation plans and studies rather than rely upon outmoded and inaccurate models redolent of political and sociological theory of the 1950s and 1960s. We argue that new policy-relevant models can be designed that take governance issues into account, which can better address the complexity associated with climate change adaptation than recommendations based solely upon existing assessments.

Like the IPCC, we argue in favor of including policy and governance considerations directly within vulnerability and adaptation assessments and plans, considerations that are noticeably lacking in most adaptive planning exercises to date, such as the Australian, Canadian, and American forest policy efforts. We argue that the few overt discussions of governance included in existing forest sector frameworks and plans have been pitched at too high a level of abstraction. Their focus on 
macro ecological and social systems-level variables has ignored or minimized the key role played in public policy decision-making by meso or middle range variables such as constitutional structures and electoral and administrative considerations, as well as more microlevel variables related to the nature of public policy decision-making processes in democratic states (Nilsson et al. 2011, Voß and Borneman 2011). While the few existing climate change models focused at the macro level point in the right direction when they acknowledge the importance of institutions and governance, they fail to connect with the new generation of case studies that identify the obstacles to change at the level of governance. Better modeling and research is needed to understand the multiple polycentric aspects of governance relations. As Voß and Bornemann (2011) concluded in their study of adaptive management:

Politics cannot be escaped or bypassed, nor eliminated or completely controlled by governance designs, but they can be analyzed and reflected on in order to devise more robust design strategies for new reflexive forms of governance. This is what we hope to encourage and support with the provision of this framework and sketching of avenues for further research.

Fortunately, those practitioners undertaking existing or future vulnerability assessment frameworks can draw upon a rich governance and public policy literature in improving both their analyses and their recommendations and prescriptions.

Responses to this article can be read online at:

http://www.ecologyandsociety.org/issues/responses. $\mathrm{php} / 5685$

\section{LITERATURE CITED}

Adger, W. 2006. Vulnerability. Global Environmental Change 16(3):268-281. http://dx.doi.org/10.1016/j.

gloenvcha.2006.02.006

Adger, W. N., S. Agrawala, P. Aggarwal, and J. Alcamo. 2007. Summary for policy-makers. Pages 7-22 in M. L. Parry, O. Canziani, J. P. Palutikof, C. Hansen, and P. van der Linden, editors. Climate change 2007: impacts, adaptation and vulnerability. Contribution of Working Group II to the Fourth Assessment Report of the Intergovernmental Panel on Climate Change. Cambridge University Press, Cambridge, UK.

Aligica, P., and V. Tarko. 2011. Polycentricity: from Polanyi to Ostrom, and beyond. Governance 25(2):237-262. http://dx. doi.org/10.1111/j.1468-0491.2011.01550.x
Almond, G. 1965. A developmental approach to political systems. World Politics 17:183-214. http://dx.doi. org/10.2307/2009347

Ascher, W. 2001. Coping with complexity and organizational interests in natural resource management. Ecosystems 4 (8):742-757. http://dx.doi.org/10.1007/s10021-001-0043-y

Barber, B. 1956. Structural-functional analysis: some problems and misunderstandings. American Sociological Review 21(2):129-135. http://dx.doi.org/10.2307/2088512

Black, M. 1961. Some questions about Parsons' theories. Pages 268-288 in M. Black, editor. Social theories of Talcott Parsons. Prentice Hall, Englewood, New Jersey, USA.

Brooks, N., N. Adger, and P. M. Kelly. 2005. The determinants of vulnerability and adaptive capacity at the national level and the implications for adaptation. Global Environmental Change 15(2):151-163. http://dx.doi.org/10.1016/j.gloenvcha.2004.12.006

Brown, H. C. P. 2009. Climate change and Ontario forests: prospects for building institutional adaptive capacity. Mitigation and Adaptation Strategies for Global Change 14 (6):513-536. http://dx.doi.org/10.1007/s11027-009-9183-8

Canadian Council of Forest Ministers. 2012. Climate change. [online] URL: http://www.ccfm.org/english/coreproducts-cc. asp

Carpenter, S. R., and W. A. Brock. 2008. Adaptive capacity and traps. Ecology and Society 13(2):40. [online] URL: http:// www.ecologyandsociety.org/vol13/iss2/art40/

Chilcote, R. H. 1994.Theories of comparative politics: the search for a paradigm reconsidered. Second edition. Westview Press, Boulder, Colorado, USA.

Cockfield, G., T. Maraseni, L. Buys, J. Sommerfeld, C. Wilson, and W. Athukorala. 2011. Socioeconomic implications of climate change with regard to forests and forest management. Contribution of Work Package 3 to the Forest Vulnerability Assessment, Gold Coast, Australia, National Climate Change Adaptation Research Facility.

Cummins, R. 1975. Functional analysis. Journal of Philosophy 72(20):741-765. http://dx.doi.org/10.2307/2024640

Daedlow, K., V. Beckmann, and R. Arlinghaus. 2011. Assessing an adaptive cycle in a social system under external pressure to change: the importance of intergroup relations in recreational fisheries governance. Ecology and Society 16(2): 3. [online] URL: http://www.ecologyandsociety.org/vol16/ iss $2 / \operatorname{art} 3 /$

D'Alessandro, S., T. Luzzati, and M. Morroni. 2010. Energy transition towards economic and environmental sustainability: feasible paths and policy implications. Journal of Cleaner Production 18(6):532-539. 
Davidson, D. J. 2010. The applicability of the concept of resilience to social systems: some sources of optimism and nagging doubts. Society \& Natural Resources 23:1135-1149. http://dx.doi.org/10.1080/08941921003652940

de Bruijn, J. A., and E. F. ten Heuvelhof. 1995. Policy networks and governance. Pages 161-179 in D. L. Weimer, editor. Institutional design. Kluwer Academic Publishers, Boston, Massachusetts, USA. http://dx.doi.org/10.1007/978-94-011-0641-2 8

Doelle, M., C. Henschel, J. Smith, C. Tollefson, and A. Wellstead. 2012. New governance arrangements at the intersection of climate change and forest policy: institutional, political and regulatory dimensions. Public Administration 90 (1):37-55. http://dx.doi.org/10.1111/j.1467-9299.2011.02006. $\underline{\mathrm{x}}$

Easton, D. 1965. A systems analysis of political life. Wiley, New York, USA.

Elster, J. 1985. Ulysses and the sirens. Cambridge University Press, Cambridge, UK.

Elster, J. 1986. An introduction to Karl Marx. Cambridge University Press, New York, New York, USA. http://dx.doi. org/10.1017/CBO9781139163620

Enderlein, H., S. Wälti, and M. Zürn. 2011. Handbook on multi-level governance. Edward Elgar Publishing.

Engle, N., and M. Lemos. 2010. Unpacking governance: building adaptive capacity to climate change of river basins in Brazil. Global Environmental Change 20:4-13). http://dx. doi.org/10.1016/j.gloenvcha.2009.07.001

Folke, C. 2006. Resilience: the emergence of a perspective for social-ecological systems analyses. Global Environmental Change 16. http://dx.doi.org/10.1016/j.gloenvcha.2006.04.002

Folke, C., S. Carpenter, T. Elmqvist, L. Gunderson, C. S. Holling, and B. Walker. 2002. Resilience and sustainable development: building adaptive capacity in a world of transformations. AMBIO: A journal of the human environment 31(5):437-440.

Fréchette, A., and N. Lewis. 2011. Pushing the boundaries of conventional forest policy research: analyzing institutional change at multiple levels. Forest Policy and Economics 13 (7):582-589. http://dx.doi.org/10.1016/j.forpol.2011.06.012

Füssel, H.-M., and R. J. T. Klein. 2006. Climate change vulnerability assessments: an evolution of conceptual thinking. Climate Change 75:301-329. http://dx.doi. org/10.1007/s10584-006-0329-3

Gale, F. 2008. Tasmania's Tamar Valley pulp mill: a comparison of planning processes using a good environmental governance framework. Australian Journal of Public
Administration 67(3):261-282. http://dx.doi.org/10.1111/ j.1467-8500.2008.00586.x

Gallopin, G. 2006. Linkages between vulnerability, resilience, and adaptive capacity. Global Environmental Change 16:293303. http://dx.doi.org/10.1016/j.gloenvcha.2006.02.004

Gatto, A. 2006. The law and governance debate in the European Union. Discussion Paper. International Institute for Labour Studies, Geneva, Switzerland.

Gilabert, P., and H. Lawford-Smith. 2012. Political feasibility: a conceptual exploration. Political Studies 60:809-825. http:// onlinelibrary.wiley.com/doi/10.1111/j.1467-9248.2011.00936. x/abstract. http://dx.doi.org/10.1111/j.1467-9248.2011.00936. $\underline{x}$

Gómez, E. J. 2011. An alternative approach to evaluating, measuring, and comparing domestic and international health institutions: insights from social science theories. Health Policy 101(3):209-219. http://dx.doi.org/10.1016/j. healthpol.2010.08.020

Government of Ontario. 2011. Climate ready: Ontario's adaptation strategy and action plan (2011-2014). [online] URL: http://www.mnr.gov.on.ca/stdprodconsume/groups/lr/ @ene/@ resources/documents/resource/stdprod 085423.pdf

Greenstein, H. 1973. The logic of functional explanations. Philosophia 3(2-3):247-264. http://dx.doi.org/10.1007/ $\underline{\mathrm{BF} 02380252}$

Gregor, A. J. 1968. Political science and the uses of functional analysis. American Political Science Review 62:425-439. http://dx.doi.org/10.2307/1952938

Groth, A. 1970. Structural functionalism and political development: three problems. Western Political Quarterly 23:485-499. http://dx.doi.org/10.2307/446568

Gupta, J., C. J. A. M. Termeer, J. Klostermann, S. Meijerink, M. van den Brink, P. Jong, S. Nooteboom, and E. Bergsma. 2010. The adaptive capacity wheel: a method to assess the inherent characteristics of institutions to enable the adaptive capacity of society. Environmental Science \& Policy 13:459471. http://dx.doi.org/10.1016/j.envsci.2010.05.006

Hempel, C. 1959. The logic of functional analysis. Pages 271307 in L. Gross, editor. Symposium on Sociological Theory. Row, Peterson \& Co., Evanston, Illinois, USA.

Hill, M. 2007. The policy process. Fourth edition. Pearson, Harlow, Essex, UK.

Holling, C. S. 1973. Resilience and stability of ecological systems. Annual Review of Ecology and Systematics 4(1):123. http://dx.doi.org/10.1146/annurev.es.04.110173.000245 
Holling, C. S. 2001. Understanding the complexity of economic, ecological, and social systems. Ecosystems 4 (5):390-405. http://dx.doi.org/10.1007/s10021-001-0101-5

Howlett, M. 2002. Do networks matter? Linking policy network structure to policy outcomes: evidence from four Canadian policy sectors 1990-2000. Canadian Journal of Political Science 35(2):235-267. http://dx.doi.org/10.1017/ $\underline{\mathrm{S} 0008423902778232}$

Howlett, M. 2011. Designing public policies: principles and instruments. Routledge, New York, New York, USA.

Howlett, M., M. Ramesh, and A. Perl. 2009. Studying public policy: policy cycles and policy subsystems. Third edition. Oxford University Press Canada, Don Mills, Ontario, Canada.

Howlett, M., and J. Rayner. 2006a. Globalization and governance capacity: explaining divergence in national forest programmes as instances of 'next-generation' regulation in Canada and Europe. Governance 19(2):251-275.

Howlett, M., and J. Rayner. 2006b. Convergence and divergence in 'new governance' arrangements: evidence from European integrated natural resource strategies. Journal of Public Policy 26(2):167-189. http://dx.doi.org/http://dx.doi. org/10.1017/S0143814X06000511

Howlett, M, J. Rayner, and C. Tollefson. 2009. From government to governance in forest planning? Lessons from the case of the British Columbia Great Bear Rainforest initiative. Forest Policy and Economics 11:383-391. http:// dx.doi.org/10.1016/j.forpol.2009.01.003

Huitt, R. K. 1968. Political feasibility. Pages 263-276 in A. Rannay, editor. Political science and public policy. Markham Publishing Co., Chicago, Illinois, USA.

Katzenstein, P. 1978. Between power and plenty: foreign economic policies of advanced industrial states. University of Wisconsin Press, Madison, Wisconsin, USA..

Keskitalo, C. 2009. Governance in vulnerability assessment: the role of globalising decision-making networks in determining local vulnerability and adaptive capacity. Mitigation and Adaptation Strategies for Global Change 14 (2)185-201. http://dx.doi.org/10.1007/s11027-008-9159-0

Keskitalo, E. C. H., N. Klenk, R. Bullock, A. L. Smith, and D. R. Bazely. 2011. Preparing for and responding to disturbance: examples from the forest sector in Sweden and Canada. Forests 2:505-524. http://dx.doi.org/10.3390/ $\underline{\mathrm{f} 2020505}$

Klenk, N., B. W. Adams, G. Q. Bull, J. L. Innes, S. J. Cohen, and B. C. Larson. 2011. Climate change adaptation and sustainable forest management: a proposed reflexive research agenda. Forestry Chronicle 87(3):351-357.
Klijn, E. H., and J. F. M. Koppenjan. 2000. Public management and policy networks: foundations of a network approach to governance. Public Management 2(2):135-158. http://dx.doi. org/10.1080/146166700411201

Knoke, D. 1987. Political networks: the structural perspective. Cambridge University Press, Cambridge, UK. http://dx.doi.org/10.1017/CBO9780511527548

Knoke, D., and J. H. Kuklinski. 1982. Network analysis. Sage, Beverly Hills, California, USA.

Koliba, C., J. Meek, and A. Zia. 2010. Governance networks in public administration and public policy. CRC Press, New York, USA.

Kooiman, J. 1993. Governance and governability: using complexity, dynamics and diversity. Pages 35-50 in J. Kooiman, editor. Modern governance. Sage, London, USA.

Kooiman J. 2000. Societal governance: levels, models, and orders of social-political interaction. Pages 138-166 in J. Pierre, editor. Debating governance. Oxford University Press, Oxford, UK.

Landau, M. 1968. On the use of functional analysis in American political science. Social Research 35:48-73.

Lebel, L., J. M. Anderies, B. Campbell, C. Folke, S. HatfieldDodds, T. P. Hughes, and J. Wilson. 2006. Governance and the capacity to manage resilience in regional social-ecological systems. Ecology and Society 11(1):19. [online] URL: http:// www.ecologyandsociety.org/vol11/iss 1/art19/

Lilienfeld, R. 1978. The rise of systems theory: an ideological analysis. John Wiley \& Sons Inc., New York, USA.

Lindblom, C. E. 1977. The policy-making process. Yale University Press, New Haven, Connecticut, USA.

Lukes, S. 1974. Power: a radical view. Macmillan, London, USA.

Majone, G. 1975. On the notion of political feasibility. European Journal of Political Research 3:259-274. http://dx. doi.org/10.1111/j.1475-6765.1975.tb00780.x

Marsh, D., and A. McConnell. 2010. Towards a framework for establishing policy success. Public Administration 88 (2):564-583. http://dx.doi.org/10.1111/j.1467-9299.2009.01803. $\underline{\mathrm{X}}$

McConnell, A. 2010. Policy success, policy failure and grey areas in-between. Journal of Public Policy 30(3):345-362. http://dx.doi.org/10.1017/S0143814X10000152

McCool, D. 1998. The subsystem family of concepts: a critique and a proposal. Political Research Quarterly 51 (2):551-570. 
McGinnis, M., editor. 2000. Polycentricity and local public economies: readings from the workshop in political theory and policy analysis. University of Michigan Press, Ann Arbor, Michigan, USA.

Meltsner, A. J. 1972. Political feasibility and policy analysis. Public Administration Review 32:859-867. http://dx.doi. org/10.2307/974646

Merton, R. 1968. Social theory and social structure. Free Press, New York, USA.

Moe, T. M. 1984. The new economics of organization. American Journal of Political Science 28:(4):739-777.

Nelson, D.R., W. N. Adger, and K. Brown. 2007. Adaptation to environmental change: contributions of a resilience framework. Annual Review of Environment and Resources 32:395-419. http://dx.doi.org/10.1146/annurev. energy.32.051807.090348

Nilsson, M., L. Nilsson, R. Hildingsson, J. Stripple, and P. O. Eikeland. 2011. The missing link: bringing institutions and politics into energy future studies. Futures 43(10):1117-1128. http://dx.doi.org/10.1016/j.futures.2011.07.010

Norris, F. H., S. P. Stevens, B. Pfefferbaum, K. F. Wyche, and R. Pfefferbaum. 2008. Community resilience as a metaphor, theory, set of capacities, and strategy for disaster readiness. American Journal of Community Psychology 41:127-150. http://dx.doi.org/10.1007/s10464-007-9156-6

Offe, C. 1984. Contradictions of the welfare state. MIT Press, Boston, Massachusetts, USA.

Ostrom, E. 1991. Rational choice theory and institutional analysis: toward complementarity. American Political Science Review 85:237-243. http://dx.doi.org/10.2307/1962889

Ostrom, E. 2008. Polycentric systems as one approach for solving collective-action problems. SSRN eLibrary. http:// papers.ssrn.com/sol3/papers.cfm?abstract_id=1304697.

Ostrom, E. 2009. A polycentric approach for coping with climate change. Social Science Research Network eLibrary. http://dx.doi.org/10.2139/ssrn.1934353

Pal, L. 2010. Beyond policy analysis: public issue management in turbulent times. Fourth edition. Nelson Education, Toronto, Ontario, Canada.

Parsons, T. 1975. The present status of 'structural-functional' theory in sociology. Pages 110-116 in T. Parsons, editor. Social systems and the evolution of action theory. Free Press, New York, USA.

Peters, B. G. 1999. Institutional theory in political science: the "new institutionalism". Pinter, London, UK.
Plummer, R., and D. R. Armitage 2007. Charting the new territory of adaptive co-management: a Delphi study. Ecology and Society 12(2): 10. [online] URL: http://www. ecologyandsociety.org/vol12/iss2/art10/>

Preston, B., R. Westaway, and E. Yuen. 2010. Climate adaptation planning in practice: an evaluation of adaptation plans from three developed nations. Mitigation and Adaptation Strategies for Global Change 16:407-438. http:// dx.doi.org/10.1007/s11027-010-9270-X

Raitio, K. 2012. New institutional approach to collaborative forest planning on public land: methods for analysis and lessons for policy. Land Use Policy 29(2):309-316. http://dx. doi.org/10.1016/j.landusepol.2011.07.001

Rayner, J., K. McNutt, and A. Wellstead. 2013. Dispersed capacity and weak coordination: the challenge of climate change adaptation in Canada's forest policy sector. Review of Policy Research 30(1):66-90. http://dx.doi.org/10.1111/ ropr.12003

Rhodes, R. A. W. 1996. The new governance: governing without government. Political Studies 44:652-667. http://dx. doi.org/10.1111/j.1467-9248.1996.tb01747.x

Rittel, H. W. J., and M. M. Webber. 1973. Dilemmas in a general theory of planning. Policy Sciences 4:155-169. http:// dx.doi.org/10.1007/BF01405730

Rosenau, J. 1992. Governance, order, and change in world politics. Pages 1-29 in J. N. Rosenau and E.-O. Czempiel, editors. Governance without government: order and change in world politics. Cambridge Studies in International Relations 20. Cambridge University Press, Cambridge, U.K. http://dx. doi.org/10.1017/CBO9780511521775

Sabatier, P., and H. Jenkins-Smith. 1999. The advocacy coalition framework: an assessment. Pages 117-166 in P. Sabatier, editor. Theories of the policy process. Westview, Boulder, Colorado, USA.

Schlager, E., and W. Bloomquist. 1996. Three emerging theories of the policy process. Public Research Quarterly 49 (3):651-672.

Skodvin, T., A. T. Gullberg, and S. Aakre. 2010. Target-group influence and political feasibility: the case of climate policy design in Europe. Journal of European Public Policy 17 (6):854-873.

Smit, B., I. Burton, J. T. Klein, and R. Street. 1999. The science of adaptation: a framework for assessment. Mitigation and Adaptation Strategies for Global Change 4(3-4):199-213. http://dx.doi.org/http://dx.doi.org/10.1023/A:1009652531101

Smit, B., and O. Pilifosova. 2001. Adaptation to climate change in the context of sustainable development and equity. 
Pages 879-912 in J. McCarthy, O. F. Canziani, N. A. Leary, P. J. Dokken, and K. S. White, editors. Climate change 2001: impacts, adaptation and vulnerability. Contribution of the Working Group to the Third Assessment Report of the Intergovernmental Panel on Climate Change. Cambridge University Press, Cambridge, UK.

Smit, B., and J. Wandel. 2006. Adaptation, adaptive capacity and vulnerability. Global Environmental Change 16(3):282292. http://dx.doi.org/10.1016/j.gloenvcha.2006.03.008

Sprinz, D., and T. Vaahtoranta. 1994. The interest-based explanation of international environmental policy. International Organization 48(1):77-105. http://dx.doi.org/http://dx.doi. org/10.1017/S0020818300000825

Stedman, R., D. Davidson, and A. Wellstead. 2004. Risk and climate change-perceptions of policy-makers in Canada. Risk Analysis 24(5):1395-1406.

Stephens, J. 1969. The logic of functional systems analyses in political science. Midwest Journal of Political Science 13 (1):367-394. http://dx.doi.org/10.2307/2110230

Termeer, C. M., A. Dewulf, and M. van Lieshout. 2010. Disentangling scale approaches in governance research: comparing monocentric, multilevel, and adaptive governance. Ecology and Society 29.

Thorson, T. 1970. Biopolitics. Holt, Rinehard and Winston, New York, USA.

Tollefson, C., F. Gale, and D. Haley. 2008. Setting the standard: certification, governance and the Forest Stewardship Council. University of British Columbia Press, Vancouver, British Coumbia, Canada.

Tollefson, C., T.Zito, and F. Gale. 2012. Symposium overview: conceptualizing new governance arrangements. Public Administration 90:3-18.

Treib, O., H. Bähr, and G. Falkner. 2007. Modes of governance: towards a conceptual clarification. Journal of European Public Policy 14(1):1-20.

United States Department of Agriculture (USDA) Forest Service. 2010. National roadmap for responding to climate change. http://www.fs.fed.us/climatechange/pdf/roadmap.pdf

United States Department of Agriculture (USDA) Forest Service. 2011. A performance scorecard for implementing the Forest Service climate change strategy. http://www.fs.fed.us/ climatechange/pdf/performance scorecard final.pdf

von Bertalanffy, L. 1969. General systems theory: foundations, development, applications. Revised. George Braziller, Inc., New York, New York, USA.
Voß, J., and B. Bornemann. 2011. The politics of reflexive governance: challenges for designing adaptive management and transition management. Ecology and Society 16(2):9. [online] URL: http://www.ecologyandsociety.org/vol16/ iss2/art9/main.html

Voss, J., D. Bauknecht, and R. Kemp, editors. 2006. Reflexive governance for sustainable development. Edward Elgar, Cheltenham, UK.

Walker, J., and M. Cooper. 2011. Genealogies of resilience: from systems ecology to the political economy of crisis adaptation. Security Dialogue 42(2):143-160. http://dx.doi. org/10.1177/0967010611399616

Wall, E., and K. Marzall. 2006. Adaptive capacity for climate change in Canadian rural communities. Local Environment 11:373-397. http://dx.doi.org/10.1080/13549830600785506

Weible, C., T. Heikkila, P. deLeon, and P. Sabatier. 2012. Understanding and influencing the policy process. Policy Sciences 45(1):1-21. http://dx.doi.org/10.1007/s11077-011-9143-5

Weick, K. 1974. Middle range theories of social systems. Behavioral Science 19:357-367. http://dx.doi.org/10.1002/ bs.3830190602

Wellstead, A. M., and R. C. Stedman. 2007. Coordinating future adaptation polices across Canadian natural resources. Climate Policy 7(1):29-45. http://dx.doi.org/http://dx.doi. org/10.3763/cpol.2007.0703

Wellstead, A., and R. Stedman. 2011. Climate change policy capacity at the sub-national government level. Journal of Comparative Policy Analysis: Research and Practice 13:461478. http://dx.doi.org/10.1080/13876988.2011.605937

Williamson, T. B. M. A. Campagna, and A. E. Ogden. 2012. Adapting sustainable forest management to climate change: a framework for assessing vulnerability and mainstreaming adaptation into decision making. Canadian Council of Forest Ministers, Ottawa, Ontario, Canada.

Wilson, R., and S. Turton. 2010. Climate change adaptation options, tools and vulnerability. Contribution of Work Package 4 to the Forest Vulnerability Assessment, Gold Coast, Australia, National Climate Change Adaptation Research Facility.

Wu, X., M. Ramesh, M. Howlett, and S. Fritzen. 2010. The public policy primer: managing public policy. Routledge, London, UK.

Zito, A. 2007. European Union: Shifting environmental governance to the supranational level. Pages 140-172 in A. Breton, G. Brosio, S. Dalmazzone, and G. Garrone, editors. Environmental governance and decentralisation. Edward Elgar, Cheltenham, UK. 
${ }^{[1]} 425$ citations in Google Scholar as of February 5, 2013-a very large number for a social science article in its first seven years after publication

${ }^{[2]}$ Williamson et al. (2012) borrowed heavily from Füssel and Klein (2006) in developing the CCFM framework.

${ }^{[3]}$ These contributions are based on a Google Scholar search of articles with more than 400 citations.

${ }^{[4]}$ Similarly, radical European political economists, most notably Louis Althusser and Nico Poulantzas, developed highly abstract structural functionalist theories of the state based on a similar logic.

${ }^{[5]}$ While some authors like Keskitalo (2009) do note the importance of "multi-level governance networks" in vulnerability assessments, they do not specify their content or impact. 